\title{
Transportation decisions of small businesses in Soweto: Balancing responsiveness and efficiency
}

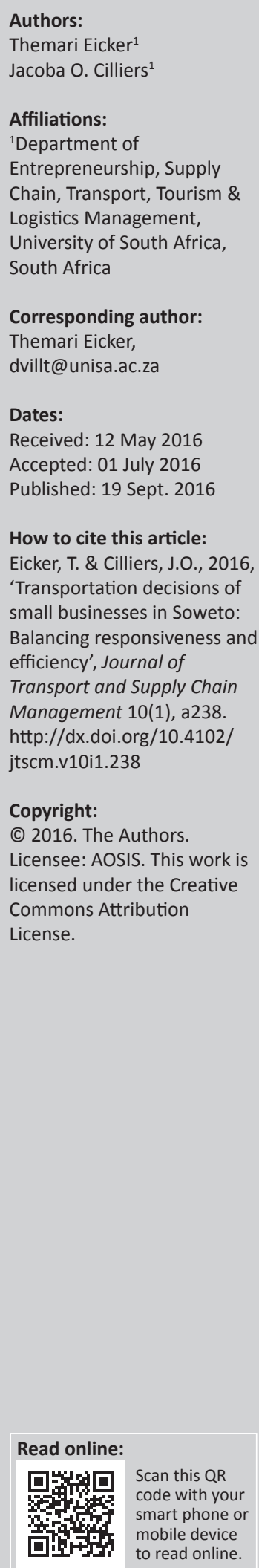

Background: The performance of small businesses makes an important contribution to the South African economy. Although the South African government implemented various initiatives for the development of small businesses in townships, the full advantage of such initiatives has not yet been experienced.

Objectives: To investigate how formal, independent small retail businesses operating in Soweto manage transportation as a logistical supply chain driver to be financially sustainable.

Method: During 2014, a survey was conducted among a sample of 556 formal, independent small retail businesses in Soweto to determine if these retailers focused on responsiveness or cost-efficiency when managing their logistical supply chain driver of transportation.

Results: The results showed that the retailers manage transportation decisions by focusing on either cost-efficiency or responsiveness, depending on the type of transportation decision and the industry in which the retailer operates. In terms of the profile of the older businesses (5 years and older) that showed a growth pattern in income (turnover) over the past year, responsive transportation decisions based on having inventory available (either by direct delivery by suppliers or by using own transportation) was a higher priority than considering cost.

Conclusion: The type of transportation decisions made by the older, growing businesses could serve as an example to younger businesses showing a stagnating or contracting growth pattern.

\section{Introduction}

The economic role that small businesses play worldwide lies in their contribution to the increased income and prosperity of individuals and the community (Abor \& Quartey 2010:218; Aykan, Aksoylu \& Sönmez 2013:939; Katz \& Green 2012:14; Mbonyane \& Ladzani 2011:550; Samujh 2011:17). In South Africa too, small businesses are vital in creating employment and ensuring a more equal distribution of income to citizens to enhance the economic growth of the country in the long run (Nkosi, Bounds \& Goldman 2013:1). In the National Development Plan 2030, the continued commitment of the South African government to prioritise the development of small businesses is reflected in their ambitious goal for the small-business sector of creating $90 \%$ of the employment opportunities within South Africa by 2030 (Department: The Presidency 2012). In setting this goal, the South African government states that small businesses should not only be developed but the owners or managers of these businesses must also be equipped with the necessary managerial skills (Department: The Presidency 2012). The focus of the National Development Plan 2030 in townships was to develop both small businesses and their owners or managers. The development of township small businesses have been characterised by dramatic interventions and subsequent changes, as discussed below.

\section{Background}

A township is a unique South African living area for black people. Townships were established during the apartheid era with the purpose of keeping African people from white residential areas (World Bank 2014:4). In the post-apartheid period (after 1994), the newly elected government immediately prioritised the development of black-owned businesses (in townships and elsewhere) as part of developing the South African small-business economy (Rogerson \& Rogerson 1997:33). Because the City of Johannesburg prioritised the full integration of Soweto into the City of Johannesburg and stimulating Soweto's economic activity, the Soweto Retail Strategy was formulated in 2005, whereafter the 5-year Soweto Economic Development Plan 2008-2013 followed. These initiatives helped to develop approximately 70000 square metres of retail space 
and included the establishment of four large shopping malls (Department of Finance and Economic Development 2005:4; Grant 2010:610; Zondi 2011:4). The development of the retail industry in Soweto had a positive impact not only on the township in terms of increasing employment opportunities and stimulating economic growth (Gauteng Quarterly Bulletin 2012:26) but also in influencing the management of these businesses as opposed to how they were operated in the previous basic retail infrastructure (Nkosi et al. 2013:4; Strydom 2011:151). Although Soweto had moved from unplanned, scattered formal and informal businesses to a township with modern shopping centres by 2012 (Strydom 2015:463), the retail patronage of Sowetan retailers showed that high-value items were still mainly bought outside the township by the high-income group and that the individuals shopping within the boundaries of the township come from the middle- to lower-income groups (Strydom 2013:2870). Therefore, it seems that Sowetan retailers are mainly serving those price-sensitive customers who still shop within the township boundaries. Despite the numerous initiatives and development plans implemented by the South African government, township small businesses still face certain challenges, such as the increase in retail foreign-owned businesses, the absence of operating facilities for small businesses, difficulty in entering a new market, a lack of relevant market information and the limited skills of entrepreneurs to run their small business efficiently (Gauteng Department of Economic Development 2014:4-5). Therefore, the Gauteng Department of Economic Development developed the Gauteng Township Economy Revitalisation Action Plan in 2014 to eliminate these challenges and enable township small businesses to contribute to a sustainable South African economy.

In a study on the economy of townships conducted by the World Bank in 2014, the underdeveloped linkages between local and formal supply chains, which most probably prevented township businesses reaching their full potential, were highlighted. Three quarters of the total spending within townships are on products that are produced outside the township and retailed through a formal or informal supply chain (World Bank 2014:13). As a result, the World Bank Report stressed the development and strengthening of supply chains within townships (World Bank 2014:22-23), which necessitates increased knowledge of supply chain management (SCM) principles among small-business owners or managers.

\section{Problem statement}

The general importance of SCM has increased, based on the shift from businesses competing against one another to entire supply chains competing against one another (Alfalla-Luque, Mendina-Lopez \& Dey 2013:800; Qrunfleh \& Tarafdar 2013:571; Simon et al. 2015:28). Because of the strategic role SCM plays in enhancing a competitive advantage, the formulation of relevant supply chain strategies is cardinal in minimising system-wide costs (being cost-efficient), while satisfying customers' service-level requirements (being effective) (Qrunfleh \& Tarafdar 2013:571). In 1997, Fisher developed a revolutionary and basic framework for selecting the most appropriate supply chain strategy (i.e. being either more cost-efficient or more responsive) based on the type of product (functional or innovative) sold and the demand (certain or uncertain) for the product.

Chopra and Meindl (2016:56) explain that obtaining the correct level of responsiveness and cost-efficiency required by the specific supply chain strategy depends on the unique interaction of the different elements within the supply chain, known as supply chain drivers. The six supply chain drivers can be divided into two broad categories, namely logistical (transportation, inventory and facilities) and cross-functional (information, sourcing and pricing). The aim of this article is to investigate how formal, independent small retail businesses operating in Soweto manage transportation as a logistical supply chain driver. Considering the challenges that small businesses face in townships and the importance of SCM in the development and strengthening of local and formal supply chains, the following research problem can be formulated:

- How can owners or managers of formal, independent small retail businesses manage the logistical supply chain driver of transportation to be financially sustainable?

This article aims to identify the profile of the businesses in terms of their performance (age and growth patterns over the past year) when managing transportation as a supply chain driver. Through descriptive and inferential analyses, it will be determined whether these retailers manage transportation to focus more on either responsiveness or cost-efficiency and whether respondents from different industry groups differ with regards to their transportation decisions.

\section{Literature review}

This section gives an overview of transportation as a logistical supply chain driver and the aspects that might influence transportation decisions. Transportation entails the moving of inventory from one point to another point in the supply chain, as products are seldom produced, sold and consumed at the same location and supports the economic utilities of place and time (Chopra \& Meindl 2016:64; Goldsby, Iyengar \& Rao 2014:3). This movement of raw materials, semifinished goods and inventory between suppliers, internal business functions and customers is the reason why transportation is regarded as one of the most important drivers in a business's supply chain (Goldsby et al. 2014:4-5; Nwaogbe et al. 2013:1). Transportation refers not only to transporting goods but is also used when delivering a service to a customer (such as plumbing). A business manages transportation to focus more on either responsiveness or cost-efficiency, depending on what the specific supply chain strategy stipulates. For example, the desired level of responsiveness can be achieved by a transportation mode that is fast and flexible, whereas the desired level of costefficiency can be achieved by transporting products in larger batches less frequently (Hugos 2006:36; Nel 2010:172). Small 
businesses primarily select road transportation for moving inventory, using small trucks and motor vehicles (Goldsby et al. 2014:24). Although faster transportation allows a business to be more responsive by serving its customers faster, a higher level of responsiveness usually comes at a higher cost (Hugo \& Badenhorst-Weiss 2011:179-180). An increase in the cost of transportation could subsequently increase the price of the product (Ittmann 2010:9). Coyle et al. (2013:401) state that a business with cost-efficient transportation capabilities can build a supply chain consisting of low-cost sourcing opportunities, which will allow them to compete in new markets. Transportation should never be treated as an isolated activity as it is a vital component throughout the entire supply chain (Holter et al. 2008:23). Therefore, when making transportation decisions, owners or managers should consider the impact of the decision on the other supply chain drivers, as well as the desired level of responsiveness amidst cost constraints (Chopra \& Meindl 2016:64).

The Logistics Barometer of South Africa (2015:7), published by Stellenbosch University in 2015, estimated that transportation costs in 2014 and 2015 contributed 59\% (R258 billion) and 58\% (R273bn) towards South Africa's total national logistical costs, respectively. According to the CSIR's 10th Annual State of Logistics Survey for South Africa (2014:9), possible reasons for this high percentage contribution are the spatially challenged economy of South Africa and the unstable fuel price. The 2014 World Bank study on the state of South African townships' economies concluded the following in terms of transportation decisions made by township small businesses:

- Businesses that purchase small quantities of inventory from formal wholesalers usually have to collect the inventory by using public transportation (taxis in the form of minibuses) or by hiring a small truck (referred to as a bakkie).

- Those businesses that purchase large quantities of inventory from formal wholesalers seldom have transportation costs, as these wholesalers usually provide free delivery for large orders.

- Some small businesses collaborate with others by sharing the rental of a small truck to save on transportation costs.

- Many small businesses purchase inventory from market stalls and other small businesses, which do not offer a delivery service.

- The average transportation costs borne by the owner or manager are between R300 and R350 per trip if inventory is collected from the supplier.

- Owners or managers acknowledge that keeping their transportation costs low can provide a competitive advantage (World Bank 2014:151-153, 172-173).

Taking all the literature discussed into consideration, it can be concluded that although the South African government implemented various initiatives for the development of small businesses in townships, the full advantage of such initiatives has not yet been experienced. Small-business owners or managers should structure their decisions about the supply chain drivers (as elements of the supply chain strategy) to be either responsive or cost-efficient or both. When managing transportation, small-business owners or managers should consider the trade-off between responsiveness and costefficiency in that higher levels of responsiveness could be attained at a higher cost. Based on a World Bank study, township small businesses should focus on keeping transportation costs as low as possible to maintain competitiveness.

\section{Research method and design}

In 2014, a survey was conducted among a sample of 650 formal, independent small businesses in Soweto, of which 556 were classified as retailers, according to the Standard Industrial Classification. The empirical findings presented in this article are based on the 556 formal, independent small retail businesses (hereafter referred to as 'respondents' or 'small retailers'). The primary data were collected using interviewercompleted questionnaires. Questions on various aspects of small-business management were included, such as the nature of the business, geographical location, distribution channels, internaloperations, turnover, business support, entrepreneurial acumen and demographic information. A separate section of the questionnaire focused on obtaining information on issues relating to SCM. For the purpose of this article, descriptive and inferential analyses of the small-retailers' responses were done on selected questions related to the respondents' profiles and their transportation decisions. Table 1 provides a summary of the research methodology used.

The following businesses were excluded from the sample: chain stores, franchises, street vendors on pavements and inhome businesses. The fieldworkers were instructed that if a business closed down during the 2-year period since the survey previously conducted among this respondent group in 2012, any business in the same residential area that complied with all the requirements should be used as a substitute.

The 556 retail respondents were divided into six categories according to the Standard Industrial Classification because the type of product that they sell will influence the selected supply chain strategy (Fisher 1997). The percentage of respondents in each category was as follows: grocery stores $(37.6 \%)$, hardware stores $(7.6 \%)$, general stores $(15.8 \%)$, retail services $(25.5 \%)$, eating and drinking places $(7 \%)$ and sale, maintenance and repair of vehicles and retail auto (6.5\%) (hereafter referred to as 'retail auto'). The retail service providers consist of, for example, undertakers, hairdressers, beauty salons and Internet cafes. The empirical findings are presented in the next section, starting with a profile of the 556 retailers, followed by the descriptive and inferential findings on the transportation statements.

\section{Results and discussion of results Profile of the retailers}

In order to establish a profile of the retail businesses, questions were included pertaining to the age and performance of the business. The age of the business was measured using the 
TABLE 1: Research methodology used during the 2014 Soweto study.

\begin{tabular}{ll}
\hline Survey area & Defined business areas in Soweto \\
\hline Survey population & $\begin{array}{l}\text { Small, formal, independent businesses located within business areas/stands across Soweto: } \\
\text { Stand-alone businesses } \\
\text { Independent businesses in shopping malls, industrial areas and businesses in shopping centres with 2-5, 6-10 and 10-plus surrounding } \\
\text { businesses }\end{array}$ \\
$\begin{array}{l}\text { Sample size } \\
\text { Sampling technique }\end{array}$ & Multistage quota sampling methodology \\
Sample selection & The fieldwork consultancy was supplied with a list of 650 businesses previously interviewed in 2012 \\
Sample units & Business owners or managers \\
Research instruments & Interviewer-completed questionnaires \\
Data collection methodology & Personal face-to-face interviews \\
Ethical consideration & Fieldwork was conducted within the boundaries of the ethical policy of the University \\
Analysis of data & $\begin{array}{l}\text { Descriptive analysis using frequency tables } \\
\text { Inferential analysis using the Kruskal-Wallis test, exploratory factor analysis and cluster analysis }\end{array}$ \\
\hline
\end{tabular}

TABLE 2: The respondents' rating of the occurrence of the transportation statements in percentage.

\begin{tabular}{|c|c|c|c|}
\hline Transportation statements & Never & Sometimes & Always \\
\hline My supplier(s) deliver(s) my stock directly to my store. & 40.6 & 23 & 34.7 \\
\hline I pay my supplier(s) to deliver my stock directly to my store. & 74.6 & 13.3 & 9.9 \\
\hline I pay my supplier more than my competing retailers to receive my stock faster. & 88.3 & 7.4 & 2.7 \\
\hline I collect my stock using my own transportation (using your own car). & 23.4 & 18.5 & 55.9 \\
\hline I collect my stock by making use of a transport opportunity (not using my own car). & 42.8 & 24.5 & 31.3 \\
\hline Another retailer(s) and I take turns to fetch the stock for both/all of our shops. & 66.7 & 15.5 & 16 \\
\hline I am willing to wait longer to pay less for my stock. & 78.8 & 9.9 & 9.4 \\
\hline
\end{tabular}

number of years it has been operating, and the performance of the business was measured using the average monthly turnover (income) and income change patterns over a period of a year. Of the 556 respondents, $59.4 \%$ had been in existence for 5 years or longer, $55.2 \%$ indicated that they had an average turnover of between R5000 and R30 000 during the past month and $73.4 \%$ indicated that their businesses had remained the same or grown in turnover (income) during the past year. Evidently, the retailers survive despite the challenges of operating within a township, as the majority have existed for 5 years or longer. Being in business for 5 years and longer is seen as a measure of success worldwide. The Small Business Advocacy (2014), a U.S. government agency supporting small businesses, indicates that half of all small businesses close down by the fifth year of trading, which is in line with the findings of the official statistics of the United Kingdom (Deakins \& Freel 2012:19).

\section{Transportation statements}

The transportation statements that were included in the questionnaire are provided in Table 2 . These statements were self-designed after consulting different decision components that influence the management of transportation. The respondents had to indicate whether they never, sometimes or always performed the specific activity related to the transportation of their inventory. These are expressed in percentages in Table 2. Frequency tables were used to show the descriptive analyses of the 556 responses. Further inferential analyses were conducted using the KruskalWallis test to determine whether the respective industry groups differed with regards to their responses on the transportation statements, followed by a factor analysis and cluster analysis to investigate the focus of transportation decisions when businesses show certain performance patterns.

\section{Descriptive analyses of the transportation statements}

The descriptive findings for each transportation statement are discussed below.

\section{Direct delivery of inventory by suppliers}

When asked whether the respondents had their inventory delivered directly to their store by suppliers, the responses were distributed across the options, with $40.6 \%$ of the respondents indicating that suppliers never delivered directly to their store, $23.0 \%$ indicating that inventory was sometimes delivered directly to their store and $34.7 \%$ indicating that suppliers always delivered directly to their store. The managers or owners of township small businesses generally travelled to formal wholesalers by public transport (minibus taxis) or by hiring small trucks (bakkies) to collect the inventory for their stores (World Bank 2014:151-153, 172173), which can explain the responses of the $40.6 \%$ who never had their inventory delivered directly to their store. Collecting inventory personally at suppliers could increase the level of responsiveness of a business, as it can easily adapt to changes, for example, the day or time of inventory collection. The $34.7 \%$ of respondents who always have their inventory delivered directly to their store can be considered unique for a small business in a township, as the World Bank (2014:151-153, 172-173) suggests that larger wholesalers deliver inventory to small businesses only if the small business orders in large quantities. Not only can the respondents save on transportation costs by purchasing large quantities but the respondents can also benefit from a lower price per unit, which could increase the level of cost-efficiency. In conclusion, the direct delivery of inventory by suppliers to the respondents' stores could be based on either cost-efficiency or responsiveness. 


\section{Payment to supplier for direct delivery}

The majority $(74.6 \%)$ of the respondents indicated that they never paid a supplier to deliver inventory directly to their stores. Three possible reasons can be given for such a decision: firstly, not all respondents have their inventory delivered to their store by a supplier, which is confirmed by the previous finding where $40.6 \%$ of the respondents indicated that their suppliers never delivered directly to their stores. Thus, not having inventory delivered directly to their store by a supplier would involve no delivery costs. Secondly, the supplier from whom inventory is purchased may not offer a delivery service, such as a supplier operating from a market stall (World Bank 2014:151-153, 172-173). Thirdly, a small business may order large quantities at wholesalers; therefore, the wholesalers may deliver the inventory free of charge. If a small business orders larger quantities of inventory to qualify for free delivery, the level of cost-efficiency could be increased, as the business is saving on transportation costs as discussed in the previous finding regarding the direct delivery of inventory by suppliers. However, the owners or managers should consider that the cost of purchasing additional inventory (to qualify for free delivery) may exceed the carrying cost. This can result in the small business eventually paying more for the additional inventory and ultimately decreasing the level of cost-efficiency. In conclusion, the decision to pay a supplier for direct delivery is based on costefficiency.

\section{Higher payment than competitors for faster delivery}

Almost $90 \%$ of the respondents indicated that they would never pay a supplier more than a competitor does to receive their inventory faster. Although receiving inventory before a competitor could increase competitiveness by having inventory readily available to customers, the respondents in this study implied that they would rather wait longer to receive their inventory than increase transportation costs. They might argue that an increase in transportation costs could outweigh the possible advantage of having inventory available before a competitor does. By not paying an additional fee to receive inventory faster, the retailers are focused more on being costefficient than responsive. As transportation costs could influence the price of the product and retailers in Soweto are mainly serving price-sensitive customers (Strydom 2013:2870), an increase in the price of a product could negatively influence sales. If a small business paid a supplier more than its competitors to receive its inventory faster, it would increase responsiveness but at the same time decrease cost-efficiency, which could lead to a loss of sales because of subsequent higher prices. In conclusion, not paying more than a competitor for faster delivery indicates that the respondents focused on cost-efficiency.

\section{Collection of inventory with own car}

When asked whether the respondents use their own cars to transport inventory to their stores, the responses were distributed across the options: $23.4 \%$ indicated never, $18.5 \%$ indicated sometimes and $55.9 \%$ indicated always. The responses of the owners or managers who never used their own transport can be attributed to the fact that they might either not own cars (which is more likely) or prefer not to use their own cars for collecting inventory (for reasons such as the size of the inventory items or the quantity purchased). According to the World Bank (2014:151-153, 172-173), township small businesses that do not use their own cars to collect inventory usually use public transportation or hire small trucks for collection. Because the average cost of collecting inventory from a supplier is between R300 and R350 per trip when using public transport or hiring a small truck (World Bank 2014:152), an owner or manager who owns a car would probably find it cheaper to use his or her own car to collect the inventory than pay the fee, which explains why the majority (55.9\%) always use their own cars to collect inventory. The different responses to this transportation statement range between the desires of being responsive and cost-efficient, depending on the respondents' situation. Irrespective of the line of reasoning behind not using one's own car for inventory collection, the result showed that being cost-efficient drives this decision. Those respondents who sometimes or always $(74.8 \%)$ used their own cars to collect inventory could either be cost conscious in saving the fee associated with other transport or responsive in terms of taking control of the situation to fetch inventory themselves. This finding aligns with a previous descriptive finding in this study that the majority of respondents never pay their suppliers to have inventory delivered directly to their stores. In conclusion, the decision to use their own cars for inventory collection is based on either cost-efficiency or responsiveness.

\section{Collection of inventory using a transportation opportunity}

When asked whether the respondents use a transportation opportunity to collect inventory (and not their own cars), the responses were distributed across the options with $42.8 \%$ indicating never, $24.5 \%$ indicating sometimes and $31.3 \%$ indicating always. The high percentage that indicated that they never used a transportation opportunity confirms the previous finding that the majority of respondents used their own transport to collect inventory. Therefore, the $55.8 \%$ of respondents who sometimes or always used a transport opportunity would be willing to pay the transportation fee (R300 - R350 per trip) as indicated by the World Bank (2014:151-153, 172-173). In conclusion, the main reason behind making use of transportation opportunities (and not one's own car) seems to be based on cost-efficiency.

\section{Collaborating with other retailers}

Almost $67 \%$ of respondents indicated that they never collected inventory on one another's behalf, which could be an indication of a silo mentality and the fact that the respondents have not yet realised the synergistic advantages of working with others. Respondents seem to take sole responsibility for collecting their inventory from suppliers, which could be a reflection of a focus on responsiveness. By functioning on their own in terms of collecting inventory, retailers show a preference for having more control in the situation; for example, the time and speed of collection. In 
contrast, the World Bank (2014:151-153, 172-173) reports that, in general, the owners or managers in townships seem to be more focused on cost-efficiency and collaborate to collect both parties' inventory. In conclusion, it seems that because the retailers have not realised and/or experienced the benefits of collaboration in terms of cost savings, their focus is probably more on being responsive, which could be more costly.

\section{Willingness to wait longer for inventory to pay less}

To the question whether the respondents were willing to wait longer for inventory in an effort to pay less, almost $80 \%$ indicated never. Such a response could imply that the smallbusiness respondents would rather be responsive in terms of having inventory available than forfeit a sale.

The results of the descriptive analyses suggest that the retail respondents seem not to be focused solely on either being cost-efficient or responsive when managing the transportation supply chain driver. In order to gain more insight into the responses on the transportation statements, inferential analyses were conducted to determine whether there was a difference among the six industries with regards to their agreement on the transportation statements (see Table 3).

\section{Inferential analyses of the transportation statements}

The Kruskal-Wallis one-way analysis of variance by ranks test was used to determine whether the different industry respondent groups differed with regards to the different transportation statements. The discussion on the inferential analyses is structured to first state the relevant hypothesis, followed by the statistical analyses.

The following hypothesis was formulated:

- Hypothesis 1: There is a difference between the type of industry with regards to their agreement on how frequently (never, sometimes, always) they:

- have stock delivered directly to their store by their suppliers

- pay their suppliers to deliver stock directly to their store

- pay their suppliers more than their competing retailers to receive stock faster

- use their own transportation to collect stock from suppliers

- use a transportation opportunity to collect stock from suppliers
- take turns with another retailer or retailers to fetch stock for both shops

- are willing to wait longer to pay less for stock.

The results of the Kruskal-Wallis test are shown in Table 3.

The results showed that no statistically significant difference existed at the $5 \%$ level of significance (all $p$ values $>0.05$ ) between the different industry groups with regards to their agreement on how frequently (never, sometimes, always) they:

- pay their suppliers to deliver their stock directly to their store

- pay a supplier more than their competing retailers to receive stock faster

- use a transportation opportunity to collect stock from suppliers

- take turns with other retailers to fetch stock for both shops.

The reason for there being no statistically significant differences between the six industries with regard to these four transportation statements can be deduced from the fairly similar mean ranks. Having similar mean ranks between the different industry groups indicates that all six industries show a similar frequency distribution with regard to how frequently they pay their suppliers to deliver inventory directly to their stores, pay a supplier more than competing retailers to receive inventory faster, use a transportation opportunity to collect inventory from suppliers and take turns with other retailers to fetch inventory.

The results of the remaining transportation statements showed that a statistically significant difference existed at the $5 \%$ level of significance (all $p$ values $<0.05$ ) between the different industry types with regards to their agreement on how frequently (never, sometimes, always) they:

- have stock delivered directly to their store by their suppliers

- use their own transportation to collect stock from suppliers

- are willing to wait longer to pay less for their stock.

This means that all six industries do not show a similar frequency distribution with regard to how frequently they have inventory delivered directly to their store by suppliers, use their own transportation to collect inventory from suppliers and are willing to wait longer to pay less for inventory. To further investigate the differences in the

TABLE 3: Kruskal-Wallis test results.

\begin{tabular}{|c|c|c|c|c|c|c|c|}
\hline $\begin{array}{l}\text { Kruskal-Wallis test } \\
\text { results }\end{array}$ & $\begin{array}{l}\text { Stock delivered } \\
\text { directly to the store } \\
\text { by suppliers }\end{array}$ & $\begin{array}{l}\text { Pay suppliers to } \\
\text { deliver stock } \\
\text { directly to the store }\end{array}$ & $\begin{array}{l}\text { Pay a supplier more } \\
\text { than competing } \\
\text { retailers to receive } \\
\text { stock faster }\end{array}$ & $\begin{array}{c}\text { Use own } \\
\text { transportation to } \\
\text { collect stock from } \\
\text { suppliers }\end{array}$ & $\begin{array}{l}\text { Use transportation } \\
\text { opportunity to } \\
\text { collect stock }\end{array}$ & $\begin{array}{l}\text { Take turns with } \\
\text { other retailers to } \\
\text { fetch stock }\end{array}$ & $\begin{array}{l}\text { Willing to wait } \\
\text { longer to pay less } \\
\text { for stock }\end{array}$ \\
\hline Chi-square & 13.010 & 8.639 & 4.596 & 20.269 & 5.297 & 9.929 & 19.463 \\
\hline$D f$ & 5 & 5 & 5 & 5 & 5 & 5 & 5 \\
\hline $\begin{array}{l}\text { Asymptotic } \\
\text { significance }\end{array}$ & 0.023 & 0.124 & 0.467 & 0.001 & 0.381 & 0.077 & 0.002 \\
\hline
\end{tabular}


TABLE 4: Mean ranks of the type of industry and the different transportation statements that show a statistical significant difference.

\begin{tabular}{|c|c|c|c|}
\hline \multirow[t]{2}{*}{ Industry } & \multicolumn{3}{|c|}{ Mean rank } \\
\hline & $\begin{array}{l}\text { Stock delivered directly to their } \\
\text { stores by suppliers }\end{array}$ & $\begin{array}{l}\text { Use own transportation to collect } \\
\text { stock from suppliers }\end{array}$ & $\begin{array}{l}\text { Willing to wait longer to pay } \\
\text { less for stock }\end{array}$ \\
\hline Retail grocery & 285.94 & 258.61 & 285.76 \\
\hline Retail hardware & 330.34 & 270.34 & 272.82 \\
\hline Retail general store & 243.06 & 319.55 & 240.32 \\
\hline Retail service & 258.90 & 246.76 & 272.37 \\
\hline Eating and drinking places & 263.15 & 306.72 & 242.58 \\
\hline Retail auto & 284.84 & 301.39 & 317.51 \\
\hline
\end{tabular}

frequency distribution of these transportation statements and the six industries, the mean ranks (provided in Table 4) of these transportation statements are considered. The mean ranks are the sum of the ranks, assigned in ascending order to all observations, for a specific subgroup divided by the number of observations for each subgroup or category. As the mean rank indicates a relative position, an industry with the highest mean rank indicates that this industry will have a higher frequency of delivery of inventory and willingness to wait longer for inventory in comparison to the other two groups. Furthermore, a mean rank does not indicate a fixed point on a scale; it only shows a tendency to the left or right anchor points of a scale.

Therefore, retail hardware stores tend to have inventory delivered directly to their stores more frequently (highest mean rank of 330.34) than the remaining industry groups. A reason could be that the characteristics of the products sold by retail hardware stores require a specialised truck to transport large items. Respondents with a retail general store indicated that they tended to collect inventory more frequently using their own transportation than the remaining industry groups (highest mean rank of 319.55). Using their own transportation could be because of the ease of transporting the items and/or the speed at which items can be brought to the store. Another possible reason could be the preference of the owner or manager to have more control over the delivery process. Retail auto respondents tended to be more frequently willing to wait longer for inventory in an effort to pay less for the inventory (highest mean rank of 317.51) than the remaining industry groups. In terms of retail auto owners or managers, they sometimes had no choice than to wait for inventory items because the correct item might be sent from overseas or from auto-manufacturer in an area outside Soweto. Retail auto parts are sometimes only dispatched once the order is large enough in an effort to save on delivery costs.

In examining the inferential analyses on the different industry groups with regards to their transportation decisions, it can be concluded that retail hardware stores manage transportation more responsively than the other industries. Depending on the motive for using their own car, retail general store owners or managers could be focused on either responsiveness or cost-efficiency. If considering the World Bank's (2014) findings, the most probable reason would be to save on transportation costs, which could mean their decision is based more on cost-efficiency. Retail auto respondents tended to be willing to wait longer for inventory in an effort to pay less for the inventory, probably because of the waiting time associated with ordering retail auto inventory items and the saving in delivery costs if full batches are delivered (showing their focus on cost-efficiency).

Having analysed the responses to the transportation statements, also across industries, the next step in the inferential analysis was to determine the effect of age and growth patterns (as indicators of financial sustainability) of the respondents on transport decisions (as indicated by responses on the transportation statements).

\section{Exploratory factor analysis}

In order to further investigate the seven transportation statements, an exploratory factor analysis was undertaken to determine if any clear constructs emerged. To enable the data reduction of the seven transportation statements, principal component extraction with varimax rotation was conducted. Because the Kaiser-Olkin measure of sampling adequacy (0.64) is above the recommended threshold of 0.5 and the Bartlett's test of sphericity is significant $(p=0.000)$, a factor analysis is appropriate. The factor analysis identified three factors, based on the eigenvalue criterion of eigenvalues larger than 1, which explains the $67.6 \%$ of the variance. The values of the factor loading are shown in the rotated component matrix in Table 5.

The three transportation factors are labelled transport dependency, financial considerations and inventory collection. Factor-based scores were subsequently calculated as the average value for the items included in each factor.

\section{Cluster analysis}

After performing a factor analysis that identified three transportation factors, a cluster analysis was performed to identify possible groupings of the data according to the variables of interest. In this analysis, the five variables were growth in income, business age (sustainability) and the three newly formed factor-based variables transport dependency, inventory collection and financial considerations. With this exploratory analysis technique, a set of objects or individuals can be grouped in such a way that clusters can be identified that show similar characteristics within the cluster.

In this analysis, a two-step cluster analysis was performed using the SPSS software package that identified three clusters (see Figure 1). The cluster quality reported a silhouette measure of cohesion and separation that was acceptable (0.3) (fair), as indicated in Figure 2. 


\begin{tabular}{lll}
\multicolumn{4}{c}{ Component } \\
\hline $\begin{array}{c}\mathbf{1} \\
\text { (Transport dependency) }\end{array}$ & \multicolumn{1}{c}{ (Financial considerations) } & (Inventory collection) \\
\hline 0.807 & - & - \\
-0.739 & 0.305 & - \\
- & - & - \\
& 0.796 & - \\
\hline & 0.713 & - \\
& - & -0.450 \\
& - & 0.925 \\
\hline
\end{tabular}

Another retailer(s) and I take turns to fetch the stock for both or all groups.

I am willing to wait longer to pay less for my stock.

I collect my stock by making use of a transport opportunity (not using my own car).

I pay my supplier(s) to deliver stock directly to my store.

I pay my supplier more than my competing retailers to receive my stock faster.

My supplier(s) deliver(s) my stock directly to my store.

I collect my stock using my own transportation (using your own car).

0.925

\begin{tabular}{|c|c|c|c|}
\hline \multicolumn{4}{|c|}{ Clusters } \\
\hline & & & 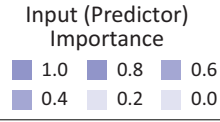 \\
\hline Cluster & 3 & 1 & 2 \\
\hline \multicolumn{4}{|l|}{ Label } \\
\hline \multicolumn{4}{|l|}{ Description } \\
\hline Size & $\begin{array}{l}45.1 \% \\
(239)\end{array}$ & $\begin{array}{l}29.4 \% \\
(156)\end{array}$ & \begin{tabular}{l|l} 
& $25.5 \%$ \\
$(135)$
\end{tabular} \\
\hline \multirow[t]{5}{*}{ Inputs } & $\begin{array}{c}\text { f2growth } \\
0.00(100.0 \%)\end{array}$ & $\begin{array}{c}\text { f2growth } \\
0.00(100.0 \%)\end{array}$ & $\begin{array}{l}\text { f2growth } \\
1.00(100.0 \%)\end{array}$ \\
\hline & $\begin{array}{c}\text { b1sustain } \\
1.00(100.0 \%)\end{array}$ & $\begin{array}{c}\text { b1sustain } \\
0.00(100.0 \%)\end{array}$ & $\begin{array}{c}\text { b1sustain } \\
1.00(57.8 \%)\end{array}$ \\
\hline & $\begin{array}{c}\text { Trans_dependency } \\
1.63\end{array}$ & $\begin{array}{c}\text { Trans_dependency } \\
1.85\end{array}$ & $\begin{array}{c}\text { Trans_dependency } \\
1.57\end{array}$ \\
\hline & $\begin{array}{c}\text { Inv_collection } \\
2.21\end{array}$ & $\begin{array}{c}\text { Inv_collection } \\
2.22\end{array}$ & $\begin{array}{l}\text { Inv_collection } \\
2.16\end{array}$ \\
\hline & $\begin{array}{c}\text { Fin_Cons } \\
1.24\end{array}$ & $\begin{array}{c}\text { Fin_Cons } \\
1.25\end{array}$ & $\begin{array}{c}\text { Fin_Cons } \\
1.27\end{array}$ \\
\hline
\end{tabular}

Source: SPSS Version 23 Output

FIGURE 1: Cluster analysis.

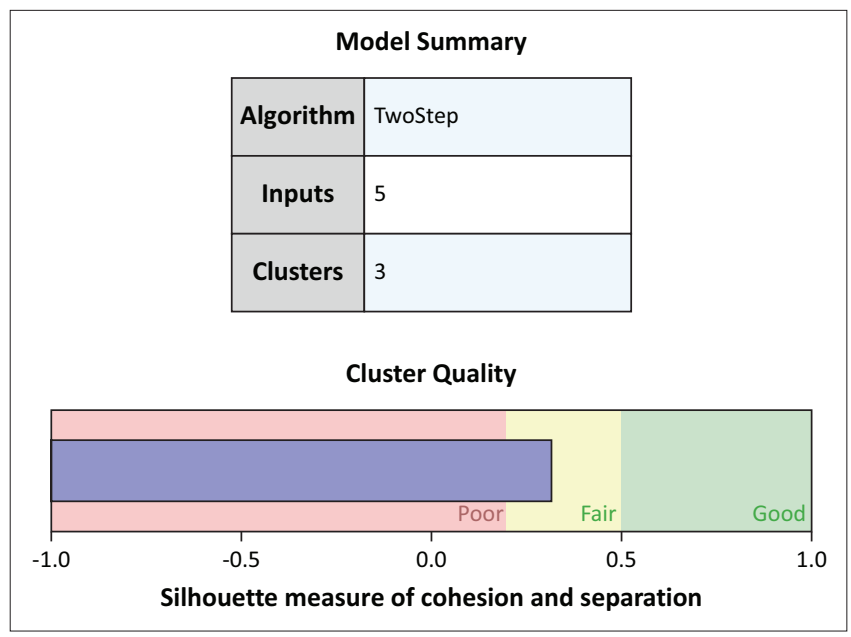

Source: SPSS Version 23 Output

FIGURE 2: Silhouette of cohesion and separation of the different clusters.
Cluster 3 represents $45.1 \%$ of the respondents, and although their businesses have contracted or stayed the same during the past year, they have survived for 5 years or more $(100 \%$ of the cluster respondents in both cases). Cluster 2 (representing $25.5 \%$ of the respondents) has been most successful on both variables in that they showed growth in the past year $(100 \%$ of cluster respondents) and have survived for 5 years and longer (57.8\% of respondents). The $29.4 \%$ respondents in cluster 1 showed a growth pattern of staying the same or contraction, as well as having survived for less than 5 years ( $100 \%$ of the cluster respondents in both cases). In cluster 3 , the three factors all had mean values that were marginally lower than what was scored in cluster 1 . However, compared to cluster 2, the mean values of cluster 3 were marginally higher than what was scored in cluster 2 on the transport dependency and inventory collection factors, but marginally lower in terms of the financial considerations factor. Because cluster 2 represents the $25.5 \%$ of businesses that have been most successful on both variables, the better transportation decisions seem to be made by cluster 2. Cluster 2 is less inclined to be transport-dependent (mean value of 1.57) than clusters 1 and 3 . Concerning inventory collection, cluster 2 (with a mean value of 2.16) also seems to be the least inclined to have their inventory delivered directly and to collect inventory using their own cars. Regarding the financial considerations value, it seems that although those businesses in cluster 2 seem to be marginally more inclined (mean rank of 1.27) than the other clusters to sometimes pay the supplier to have their inventory delivered directly, to pay more than competitors to receive their inventory faster and to wait longer for inventory in order to pay less, the mean value was still leaning more towards a 'never' response. The transportation decisions made by cluster 2 revealed that they would sometimes have the inventory delivered by the supplier or use their own car (mean value of 2.16 for inventory collection) rather than paying for delivery or waiting longer to pay less for the inventory (mean value of 1.27 for financial considerations). Cluster 2 would also be more inclined to have the inventory delivered directly or collect the inventory using their own car (mean value of 2.16 for inventory collection) than being transport-dependent by using a transport opportunity and taking turns to fetch inventory (mean value of 1.57 for transport dependency). From this analysis, the transportation decision of cluster 2 to be more inclined to have the inventory delivered or to fetch the inventory using their own transportation, with a lesser inclination to consider cost, could indicate that an emphasis 
on having the inventory available (being responsive) was a higher priority than considering cost. Such an approach to transportation to be more responsive could serve as an example for stagnating (or contracting) and younger businesses when making transportation decisions. The finding confirms the balance in cost-responsiveness trade-off in that more sales can be generated by having inventory available despite the higher cost associated with obtaining the inventory.

\section{Conclusion and recommendation}

Despite the South African government's initiatives for developing small township businesses, challenges prevail. Because SCM is discussed as a way of enhancing smallbusinesses' competitiveness, the need for enhancing business owners' SCM skills is highlighted. When formulating supply chain strategies, owners or managers should base their decisions related to supply chain drivers on being either responsive or cost-efficient or both and consider the trade-off faced in such decisions. The literature states that, in townships, the costs related to transportation supply chain drivers should be kept as low as possible to maintain competitiveness. The aim of this article was to investigate how formal, independent small retail businesses operating in the Soweto township manage transportation as a supply chain driver in terms of responsiveness and cost-efficiency to ensure financial sustainability and to determine whether the industry in which businesses operate might influence their transportation decisions. Finally, this article aimed to analyse the performance (age and growth patterns) of the businesses in order to suggest guidelines to younger businesses that showed no or negative growth patterns. Data were obtained from 556 respondents, and the empirical analysis focused on providing a profile of the respondents and how transportation is managed by these retailers.

The profile of the retailers revealed that the majority are able to operate successfully and survive amidst the challenges that they face. The majority have been in operation for 5 years or longer and showed income growth over the past year.

Regarding the management of transportation by the small retailers, the following findings were made: The direct delivery of inventory by suppliers to the retailers is managed either responsively or cost-efficiently, depending on the whether the owners or managers regard responsiveness or cost-efficiency as more important. Owners or managers who take responsibility for their own inventory collection are focused on managing transportation more responsively, whereas the owners or managers who take advantage of discounts and economies of scale are managing transportation more cost-efficiently. The inferential analysis indicated that there was a difference in the direct delivery of inventory by suppliers to Sowetan small retailers in the different industries. Retail hardware stores tended to be more responsive than the remaining industries by always having their inventory delivered to their stores, possibly because of the characteristics of the products they sell. Generally, small retailers in Soweto do not pay for the delivery of their inventory. Owners or managers will rather collect inventory themselves or purchase large quantities to qualify for free delivery, which could subsequently increase cost-efficiency. The inferential analyses indicated that no statistical difference was found between the different industry groups regarding whether they pay their suppliers to deliver their inventory directly to their store. Retail respondents would rather save on transportation costs by not paying a supplier more than competing retailers to receive inventory faster. Keeping transportation costs low could outweigh the benefits for the retailers of having inventory immediately available to customers. According to the inferential analyses, no statistical difference was found between the different industry groups and whether they paid a supplier more than competing retailers to receive inventory faster.

The decision of retail owners or managers to use (or not use) their own cars for inventory collection seems to be based on either cost-efficiency or responsiveness, depending on whether a car is owned (or not), the type of product and the personal preference of the owner or manager to have control over inventory collection. The inferential analyses showed a statistical difference between the different industry groups on whether they use their own transportation to collect their inventory from suppliers. Retail general store owners or managers, more than the other industry groups, tended to collect inventory by using their own transportation. Retail grocers could prefer using their own transportation based on the ease of transporting the items and/or the speed at which items can be brought to the store. Another reason could be the preference of the owner or manager to control the delivery process.

Although some respondents used their own transport for collecting inventory, others used a transportation opportunity, which could entail a delivery fee. The main reason for using transportation opportunities (and not one's own car) is based on cost. The inferential analyses showed no difference among the industries in terms of relying on a transportation opportunity when not using one's own car.

The results show that it has not yet dawned on the respondents that the cost savings from collaboration with other owners or managers could outweigh their preference to collect inventory themselves in an attempt to be more responsive. The inferential analyses showed that there is no difference among the different industry groups with regards to their collaboration with other retailers to take turns to fetch the inventory for both shops.

The majority response that the retailers are never willing to wait longer for inventory in an effort to pay less indicates the retailers' focus on responsiveness in that they would rather have inventory available than forfeit a sale. The inferential analyses showed a difference among the industry groups, with the retail auto group indicating that they tended to be 
willing to wait longer for inventory in an effort to pay less for the inventory, probably because of the waiting time associated with ordering retail auto inventory items and the saving in delivery costs if full batches are delivered.

Transportation is only one of the six supply chain drivers that should be managed to obtain the optimum level of responsiveness and cost-efficiency required by the supply chain strategy and cannot be viewed in isolation. After analysing the descriptive and inferential data, it was established that formal, independent small retail businesses in Soweto manage transportation in order to focus on either cost-efficiency or responsiveness, depending on the type of transportation decision made and the characteristics of the product (based on industry). Younger (less than 5 years old) businesses with no or negative growth over the past year could learn from the more successful businesses (those that are 5 years and older and showed growth over the past year); these have realised that having inventory delivered or fetching inventory to be able to serve their (mostly pricesensitive) customers is a higher priority than focusing solely on cost (as stated in the literature). Initiatives to empower small-business managers or owners should include the improvement of SCM skills in order to strengthen the much-needed supply chain linkages between townships and the urban formal business sector. Owners or managers should consider the industry in which they function when making transportation decisions. Finally, such owners or managers should carefully consider the trade-off between cost-efficiency and responsiveness and prioritise responsiveness as a decision criterion, instead of focusing solely on cost-cutting or financial measures.

Future research should include an analysis of how the remaining supply chain drivers would influence the transportation decisions made. The role of different demographic variables in supply chain driver decisionmaking in small businesses should also be investigated.

\section{Acknowledgements}

Dr M. Pohl is acknowledged for her contribution to the statistical analyses performed in this study.

\section{Competing interests}

The authors declare that they have no financial or personal relationships which may have inappropriately influenced them in writing this article.

\section{Authors' contributions}

T.E. is a postgraduate student at Unisa and this article is based on her Master's dissertation, which is still in progress. J.O.C. is the supervisor and contributed to the conceptualisation of the article, as well as analysing and recording literature and empirical findings from the dissertation.

\section{References}

Abor, J. \& Quartey, P., 2010, 'Issues in SME development in Ghana and South Africa', International Research Journal of Finance and Economics 39, 218-228.

Alfalla-Luque, R., Mendina-Lopez, C. \& Dey, P.K., 2013, 'Supply chain integration framework using literature review', Production Planning and Control 24(8-9), 800-817. http://dx.doi.org/10.1080/09537287.2012.666870

Aykan, E., Aksoylu, S. \& Sönmez, E., 2013, 'Effects of support programs on corporate strategies of small and medium-sized enterprises', Procedia-Social and Behavioral Strategies of small and medium-sized enterprises', Procedia-Social and Beh
Sciences 99, 938-946. http://dx.doi.org/10.1016/j.sbspro.2013.10.567

Chopra, S. \& Meindl, P., 2016, Supply chain management: Strategy, planning, and operation, 6th edn., Pearson, Essex.

Coyle, J.J., Langley, C.J., Novack, B.J. \& Gibson, B.J., 2013, Managing supply chains: A logistics approach, 9th edn., South-Western Cengage Learning, Canada.

CSIR, 2014, 10th annual state of logistics survey for South Africa 2013, viewed 15 November 2014, from http://www.csir.co.za/sol/

Deakins, D. \& Freel, M., 2012, Entrepreneurship and small firms, 6th edn., McGrawHill Higher Education, Berkshire.

Department of Finance and Economic Development, 2005, Soweto retail strategy, viewed 01 November 2013, from http://www.joburg.org.za/index.php?option=com viewed 01 November 2013, from http://ww

Department: The Presidency, 2012, 'National development plan 2030', viewed 23 January 2016, from http://www.gov.za/sites/www.gov.za/files/Executive $\% 20$ Summary-NDP $\% 202030 \% 20 \% 200$ ur $\% 2$ future $\% 20-\% 20$ make $\% 20$ it $\% 2$ work. pdf

Fisher, M.L, 1997, 'What is the right supply chain for your product?', Harvard Business Review, March-April, 105-116.

Gauteng Department of Economic Development, 2014, Gauteng department of economic development revitalisation strategy, viewed 23 January 2016, from http://www.ecodev.gpg.gov.za/Documents/Draft\%20GTER\%20Strat.pdf

Gauteng Quarterly Bulletin, 2012, 'The retail industry on the rise in South Africa', viewed 20 December 2015, from http://www.treasury.gpg.gov.za/Documents/ QB1\%20The $\% 20$ Retail $\% 20$ Industry $\% 20$ on $\% 20$ the $\% 20$ Rise.pdf

Goldsby, T.J., Iyengar, D. \& Rao, S., 2014, The definitive guide to transportation: Principles, strategies, and decisions for the effective flow of goods and services, Pearson Education, Upper Saddle River, NJ.

Grant, R., 2010, 'Working it out: Labour geographic of the poor in Soweto, South Africa', Development Southern Africa 27(4), 595-612. http://dx.doi.org/10.1080/ 0376835X.2010.508595

Holter, A.R., Grant, D.B., Ritchie, J. \& Shaw, N., 2008, 'A framework for purchasing transport services in small and medium size enterprises', International Journal of Physical Distribution \& Logistics Management 38(1), 21-38. http://dx.doi. Physical Distribution \& Logistics
org/10.1108/09600030810857193

Hugo, W.M.J. \& Badenhorst-Weiss, J.A., 2011, Purchasing \& supply management, 6th edn., Van Schaik, Pretoria.

Hugos, M., 2006, Essentials of supply chain management, John Wiley, Hoboken, NJ.

Ittmann, H., 2010, 'Total cost of logistics in South Africa need to be reduced', viewed 04 February 2016, from http://www.csir.co.za/publications/pdfs/2.2_SS_BE_ transport\&logistics_chap1.pdf

Katz, J.A. \& Green, R.P., 2012, Entrepreneurial small businesses, 3rd edn., McGraw-Hill, New York.

Mbonyane, B. \& Ladzani, W., 2011, 'Factors that hinder the growth of small businesses in South African townships', European Business Review 23(6), 550-560. http:// in.doi.org/10.1108/09555341111175390

Nel, J.D., 2010, 'Developing a conceptual framework to analyse supply chain design practices', Unpublished doctoral thesis, University of South Africa, Pretoria, Oasis, viewed 17 February 2015, from http://oasis.Unisa.ac.za/search $\sim$ S16?/anel/anel/ $25 \% 2 \mathrm{C} 81 \% 2 \mathrm{C} 101 \% 2 \mathrm{CE} / 2$ exact\&FF=anel+jacobus+daniel\&1\%2C2\%2C

Nkosi, E., Bounds, M. \& Goldman, G., 2013, 'Skills required for the black-owned small enterprise in Soweto', Acta Commercii 13(1), 1-10. http://dx.doi.org/10.4102/ ac.v13i1.186

Nwaogbe, O.R., Omoke, V., Ubani, E.C. \& Ukaegbu, S.I., 2013, 'Cost minimisation of product transhipment for physical distribution management', Journal of Transport and Supply Chain Management 7(1), 9. http://dx.doi.org/10.4102/ jtscm.v7i1.94

Qrunfleh, S. \& Tarafdar, M., 2013, 'Lean and agile supply chain strategies and supply chain responsiveness: The role of strategic supplier partnership and postponement', Supply Chain Management: An International Journal 18(6), 571-582.

Rogerson, C.M. \& Rogerson, J.M., 1997, 'The changing post-apartheid city: Emergent black-owned small enterprises in Johannesburg', Urban Studies 34(1), 85-103. http://dx.doi.org/10.1080/0042098976285

Samujh, H.R., 2011, 'Micro-businesses need support: Survival precedes sustainability', Corporate Governance: The International Journal of Business in Society 11(1), 15-28. http://dx.doi.org/10.1108/14720701111108817

Simon, A.T., Serio, L.C.D., Pires, S.R.I. \& Martins, G.S., 2015, 'Evaluating supply chain management: A methodology based on a theoretical model', Revista de Administração Contemporânea 19(1), 26-44. http://dx.doi.org/10.1590/1982Administração Con

Small Business Administration, 2014, Office of advocacy - Frequently asked questions, viewed 16 January 2015, from https://www.sba.gov/sites/default/files/advocacy/ FAQ_March_2014_0.pdf 
Stellenbosch University, 2015, 'Logistics barometer of South Africa', viewed 21 September 2015, from http://www.sun.ac.za/english/faculty/economy/logistics/ September 2015, from hitt://www.sun.ac.za/english/faculty/economy/log
Documents/Logistics\%20Barometer/Logistics\%20Barometer\%202015.pdf

Strydom, J.W., 2011, 'Retailing in disadvantaged communities: The outshopping phenomenon revisited', Journal of Contemporary Management 8, 150-172.

Strydom, J.W., 2013, 'Retail patronage of Sowetan consumers after 1994', African Journal of Business Management 7(29), 2863-2871. http://dx.doi.org/10.5897/ AJBM12.1133
Strydom, J.W., 2015, 'David against Goliath: Predicting the survival of formal small businesses in Soweto', International Business \& Economics Research Journal 14(3), 463-476. http://dx.doi.org/10.19030/iber.v14i3.9210

World Bank, 2014, Economics of South African townships: Special focus on Diepsloot, World Bank, Washington, DC.

Zondi, G.M., 2011, 'Investigating the social and economic effect of Jabulani and Maponya Malls on the residents of Soweto', MBA dissertation, University of Stellenbosch, Stellenbosch. 